\title{
Glossolalia, iniciação e alteridade no pentecostalismo
}

\author{
Maurício RicCI
}

\begin{abstract}
resumo $\mathrm{O}$ dom de linguas - como a glossolalia é conhecida entre os pentecostais - é um modo de orar em que o fiel, em êxtase, se expressa através de uma linguagem aparentemente ininteligível, acompanhada por expressóes corporais que produzem sentimentos de alegria, transbordamento, choro, riso, saltos e gestos. Esse dom é de importância central na Teologia Pentecostal por ser considerado, pelos crentes, a irrefutável evidência do batismo no Espirito Santo. Trata-se de um dom institucional e ritualístico, que se apresenta durante culto e se desenvolve na instituição - distintamente dos dons que ocorrem em processos relativamente autônomos, como é o caso das benzedeiras e curandeiros. Analiso o processo de aquisiçáo e desenvolvimento da glossolalia dialogando com a Antropologia do Imaginário.
\end{abstract}

palavras-chave Glossolalia. Dom. Antropologia do Imaginário.

A glossolalia encarna um fenômeno catalisador de uma complexidade de relaçóes simbólicas, portanto culturais, que se processam no interior do Pentecostalismo como uma forma de oração extática reconhecida pelas Igrejas Pentecostais como o dom de linguas. Etimologicamente, a palavra glossolalia origina-se de glossa (língua) + lalein $($ falar $)=$ falar em línguas (Oliveira Júnior, 2004, p. 30). A aquisição da glossolalia consiste no eixo principal da Teologia Pentecostal, pois é concebida como uma manifestação explícita do batismo no Espírito Santo (Oro, 1996, p. 19; Corten, 1996, p. 57; Campos Júnior, 1995, p. 24; Freston, 1996, p. 75; Mafra, 2001, p. 31). O imaginário cristão pentecostal apresenta dois tipos de batismo: por imersão, feito pelos homens, e denomi- nado batismo nas águas, e o outro, feito pelo próprio Jesus Cristo, o batismo de fogo ou batismo no Espirito Santo. Quando os fiéis estão falando em línguas, eles podem cair, deitar-se (Campos Júnior, 1995; Corten, 1996) pular, rolar, dar cambalhotas (Mariano, 1999); chorar, rir (Oro, 1996); podem sentir uma grande emoção, alegria, exultação, transbordamento (Oro, 1995), parecendo este fenômeno tão singular oscilar entre o aprisionamento e o extravasamento dos sentidos (Bastide, s/d, p. 64, 78) ${ }^{1}$. Estudei a glossolalia entre trabalhadores pobres (metalúrgicos, empregadas domésticas, pedreiros, donas de casa, faxineiras). Para conduzir esta pesquisa freqüentei os cultos pentecostais nos moldes da observação participante como é tradicionalmente construída pela antropologia, no período compreendido entre janeiro de 2004 a dezembro de 2005, numa comunidade da Igreja Assembléia de Deus, localizada na periferia de São Carlos (São Paulo), no bairro Jardim Paulistano situado próximo à rodovia Washington Luís.

A tradição bíblica entendida como uma mediação simbólica, como uma outra forma de abordagem do mundo, uma realidade mítica, coloca-nos a problemática epifânica do mistério. Nesta significação cultural e mítica, a produção de metáforas, de símbolos e de analogias seguem uma lógica redundante. A efusão do Espírito Santo e dons que dele emanam, entre eles a glossolalia, é tida pelos pentecostais, como promessa de Deus para os últimos dias, como afirma a Escritura:

1. Na glossolalia, o aprisionamento dos sentidos corresponde ao balbucio, à prece silenciosa, enquanto o extravasamento dos sentidos mobiliza a dança, o arrebatamento, algo próximo ao desfalecimento. 
e há de ser que, depois, derramarei o meu Espírito sobre toda a carne, e vossos filhos e vossas filhas profetizarão, os vossos velhos terão sonhos, os vossos jovens terão visóes (Joel, 1995, Cap. 2, vers. 28).

A figura mítica de Jesus caracterizava esse acontecimento como promessa de um outro Consolador, o Espírito Santo, que estaria com os discípulos confortando-os e capacitando-os para o serviço evangélico: "e eis que sobre vós envio a promessa de meu Pai; ficai, porém, na cidade de Jerusalém, até que do alto sejais revestidos de poder" (Lucas, 1995, Cap. 24, vers. 49).

Os discípulos cristãos interpretando essa suposta orientação de Jesus para permanecerem em Jerusalém, cinqüenta dias após a morte de Cristo, no dia de Pentecostes, presenciaram o seguinte fato conforme Atos dos Apóstolos:

\section{Cumprindo-se o dia de Pentecostes, estavam todos reunidos no mesmo lugar; e de repente, veio do céu um som, como de um vento vee- mente e impetuoso, e encheu toda a casa em que estavam assentados. E foram vistas por eles línguas repartidas, como que de fogo, as quais pousaram sobre cada um deles. E todos foram cheios do Espírito Santo, e começaram a falar em outras línguas, conforme o Espírito Santo lhes concedia que falassem (Atos dos Apóstolos, 1995, Cap. 2, vers.1-4).}

Esses acontecimentos de Pentecostes, daí o adjetivo pentecostal, foram interpretados, já pelo cristianismo nascente, como cumprimento da profecia do profeta Joel que apresentei anteriormente. Pedro, o apóstolo, ao perceber que muitos pensavam que os discípulos estavam bêbados, interpreta essa epifania:

Estes homens não estão embriagados, como vós pensais, sendo a terceira hora do dia. Mas isto é o que foi dito pelo profeta Joel: E nos últimos dias acontecerá, diz Deus, que do meu Espírito derramarei sobre toda a carne; E os vossos filhos e as vossas filhas profetizarão, os vossos jovens terão visões, e os vossos velhos sonharão sonhos (Atos dos Apóstolos, 1995, Cap. 2, vers.1517).

Os acontecimentos de Pentecostes, registrados nas Escrituras, são uma espécie de mito de origem do Movimento Pentecostal. Dizem os crentes pentecostais que é possível reviver o que aconteceu com a igreja primitiva quando da grande efusão do Espírito no Pentecostes. Daí a atualidade da glossolalia. Doutrinariamente, o Pentecostalismo enfatiza o poder do Espírito Santo, que não é um poder intelectualizado ou enclausurado no discurso da ortodoxia teológico-religiosa. Nas igrejas pentecostais, esse poder religioso é sentido, vivenciado e manipulado (Hervieu-Léger, 1997, p. 33; Oro, 1995, p. 90-91; Rolim, 1985, p. 65-66; Brandão, 1986, p. 44; Baubérot, s/d, p. 114). Mesmo sendo parte do dogma cristão da Trindade, o Espírito Santo está no primeiro plano das representaçóes míticas no interior do movimento pentecostal. A terceira pessoa da trindade é essencialmente força e poder, metaforicamente é possível ser cheio do Espirito Santo, o mesmo talvez não possa ocorrer com o Pai e o Filho; é mais comum, segundo minha observação nos cultos, ouvir que os crentes devem ser cheios do Espírito.

Os pentecostais afirmam que são três as mais importantes atribuiçôes do Espírito Santo: 1) a capacitação, orientada para o serviço evangélico, diz respeito aos dons espirituais; 2) a intercessão, nas oraçóes, os crentes dizem que o Espírito intervém junto a Deus em favor do predicador (quem ora) com gemidos inexprimiveis; 3) a consolação, o sentimento de pertença e participação do culto são mediados pelo Espírito Santo. É por meio do Espírito Santo, em especial através da glossolalia, que 
o fiel pentecostal estabelece vínculos entre si mesmo e a comunidade de crentes, a igreja a qual pertence. Na medida em que os dons espirituais concedidos podem edificar o indivíduo ou proporcionar o desenvolvimento de toda a instituição.

No pentecostalismo existe uma forte crença na atualidade dos dons espirituais, o mesmo que aconteceu no cristianismo primitivo, registrado no livro de Atos dos Apóstolos. Os milagres, as curas e as línguas de fogo podem acontecer hoje, em pleno século XXI. Essa mesma origem mítica, construída para contar a história do surgimento do dom de línguas, e de todos os outros dons do Espírito Santo, possui o intuito de edificar o fiel ou o corpo de Cristo, a Igreja. Uma distinção que constrói a categoria de dualidade nas representaçôes sobre o dom conduz os fiéis a acreditarem nela com forte ênfase: aquele que fala em línguas edifica a si mesmo, e a náo ser que alguém interprete o que se diz em êxtase, a congregação (a Igreja) é edificada, pois, todos têm acesso a mensagem divina.

Nos cultos pentecostais, muitas são as manifestações espirituais reconhecidas pelos crentes que pesquisei, dentre elas os dons de visäo (contemplação de seres divinos, anjos, demônios, objetos sagrados, animais); dons de sonhos (imagens oníricas com significado sagrado); dons de curar (habilidade em operar milagres de cura e de classificar males espirituais); dons de revelação e profecia (conhecimento daquilo que é oculto aos olhos humanos); dons da palavra, da sabedoria e da ciência (promovem habilidades especiais no conhecimento das Escrituras e das profundezas de Deus); dom de discernimento de espiritos (faculdade de estabelecer classificaçôes entre o que é de Deus e o que pertence ao Diabo). O dom de linguas e o dom de interpretação das linguas, essa fala extática que necessita de interpretação para que os outros membros da igreja a entendam, é o dom mais comum entre os fiéis. O saber relacionado aos dons do Espírito Santo, no Pentecostalismo, é engendrado pela experiência dos fiéis na vivência cotidiana do sagrado do que mediado por um racionalismo bíblico.

Os dons espirituais possuem quatro conjuntos de classificação encontrados na Bíblia: 1) apóstolo; 2) profeta; 3) doutores; 4) dons de operar milagres; 5) dons de curar; 6) socorros; 7) governos, dons administrativos; 8) variedade de línguas (I Coríntios, 1995, Cap.12 vers. 28). O segundo conjunto apresenta esses outros dons: 1) palavra da sabedoria; 2) palavra da ciência; 3) fé; 4) dons de curar; 5) operação de maravilhas; 6) profecia; 7) discernimento dos espíritos; 8) variedade de línguas; 9) interpretação de línguas (I Coríntios, 1995, Cap.12 vers. 8-10). O terceiro é assim organizado: 1) profecia; 2) ministério; 3) ensino; 4) exortação; 5) contribuiçăo; 6) liderança; 7) misericórdia (Romanos, 1995, Cap. 12 vers. 6-8). Para finalizar, o quarto conjunto: 1) apóstolo; 2) profeta; 3) evangelista; 4) pastor; 5) doutor (Efésios, 1995, Cap. 4, vers. 11).

Apesar de a Bíblia apontar os dons acima elencados os pentecostais consideram o segundo conjunto o mais importante, pois, este contém os chamados dons espirituais. Esse conjunto de dons não é estático, conforme observei em pesquisa de campo na Assembléia de Deus, pois os crentes atribuem subdivisóes a cada dom: 1) dons de curar, subdivide-se em: a) cura de doenças espirituais (desfaz trabalhos de feitiçaria e macumba); b) cura de doenças materiais (AIDS, câncer, pneumonia etc.); 2) profecia (capacidade de conhecer o passado e de prever o futuro); 3) dom de revelação (parece ser um dom que permite trazer luz sobre alguma coisa ou fato oculto); 4) dom de sonhos (mensagens premonitórias durante o sono e/ou interpretação das mesmas); 5) dom de discernimento dos espiritos, estabelece distinçôes entre o falso e o verdadeiro: a) capacidade sobrenatural de 
saber se alguém está mentindo; b) classificação das coisas de Deus e das coisas do diabo.

De modo análogo a Elda Rizzo de Oliveira, para quem aquisiçấo do dom é um marco na vida da benzedeira (Oliveira, 1992), observei a mesma função do dom para o fiel pentecostal. Para quem mal pôde freqüentar a escola, quando doente enfrenta filas em postos de saúde e hospitais, possui trabalho precário, ou seja, alguém destituído das mínimas condiçóes de existência, se percebe sendo construído através de um saber muito especifico ${ }^{2}$. Este saber não se constitui como resposta pragmática às coisas consideradas profanas, mas ele mobiliza e é mobilizado pelas formas como a cultura pentecostal dinamiza a função simbólica nos símbolos de morte-renascimento, como uma experiência de transitividade, num continuum, que abarca a todos os glossólalos.

Tal qual é conhecido no Pentecostalismo, o fenômeno da glossolalia é o entrelaçamento, de fio a fio, de uma complexa trama social, caracterizando o dom como uma quebra de fronteira entre a magia e a religião. No processo de aquisição do dom de línguas, destacamos momentos que devem ser compreendidos como passagens, que estabelecem relaçôes específicas de várias ordens no âmago do universo simbólico pentecostal. Por um lado, temos a atuação das forças de disjunção (as tragédias, o sofrimento, as doenças, os demônios), contra as quais serão manipuladas as forças de integração (a oração, a Bíblia, o Espírito Santo, Jesus Cristo). Apesar do fiel glossólalo estar sujeito à instituição, à Igreja e suas regras - pois sem a

2. Conforme ensina Oliveira, o conhecimento da benzedeira é "calcado numa experiência de cunho pessoal que se dá, não através de uma especialização formal, mas nem por isso destituído de lógicas próprias de conhecimento, regras e pressupostos que lhe asseguram uma consistência singular, contrário à redução que dele faz a visão da classe dominante, ao imprimir-lhe o rótulo de 'crendice' ou de 'coisa de ignorantes" (Oliveira, 1992, p. 16). instituição não pode haver o desenvolvimento do dom - o dom é ao mesmo tempo um fenômeno mítico e mágico.

Observado de fora, o dom de línguas parece ser uma ação que a Igreja engendra de forma uniforme sobre e entre os seus membros. Contudo, na diversidade de representaçóes construídas pelos crentes existe uma pluralidade simbólica, plena de significações, que vêm à tona mediante uma minuciosa compreensão das imagens mobilizadas nos próprios cultos. Com base em Gilbert Durand, quatro etapas podem ser identificadas no processo coletivo de construção da glossolalia: o transeo, o translatio, o transitio e o transcendo (Durand, 1997b, p. 96).

\section{Transeo: entrando no mistério}

Muitos fiéis acreditam que o dom de línguas seja uma porta de entrada para a aquisição de outros dons espirituais, como os dons de curar, de profecia, de revelação, de sonhos, de visões, da palavra, do discernimento. Essa posição também é compartilhada entre os fiéis da Renovação Carismática Católica. A partir do momento que se é batizado com o Espírito Santo e fala-se em línguas, cada fiel, potencialmente, passaria a ter os condicionantes religiosos e míticos para o despertar de outros dons, ainda que eles estejam inoperantes na vida dos crentes. Caberia ao fiel criar mecanismos para o despertar desses outros carismas, por meio da oração, do jejum, da participação nas vigílias ${ }^{3}$, da oraçáo nas matas e nos montes, das participaçôes das atividades da igreja e da submissão às normas institucionais, esses são os meios mais comuns de se alcançar os dons. Vejamos

3. As vigílias são reuniôes de oração que ocorrem no final da noite e se estendem pela madrugada adentro na própria Igreja. Costuma-se também realizar esses encontros nas matas e montes. 
em seus relatos como os fiéis elaboram o despertar do dom em suas vidas:

\section{1) crença em Deus, oração e busca da presen- ça divina:}

Para receber o dom em primeiro lugar temos que crer, em segundo lugar orar e buscar a presença de Deus, pois, todo aquele que crer verá a glória de Deus. E existem vários dons, têm pessoas que não têm o dom de línguas, mas tem o dom de revelação, dom do amor (29 anos, vendedor).

\section{2) firme crença em Deus, busca e reconheci- mento da potência da divindade:}

Para recebermos o dom temos que crer e não duvidar. Tem que reconhecer o Senhor sobre todas as coisas e buscar, pois, está escrito buscai ao Senhor enquanto se pode achar e invocai-o enquanto está perto (22 anos, metalúrgico).

\section{3) exclusividade de uma fonte primordial so- bre todas as outras fontes geradoras do dom:}

Para receber esse dom é preciso reconhecer Jesus como único salvador e buscar o dom. Para saber que uma pessoa tem o dom é preciso ter um outro dom, o dom de interpretação ou o dom de discernimento dos espíritos. Nós que somos pastores da Igreja procuramos receber esses dons para melhor administrá-la (26 anos, metalúrgico).

As situaçôes em que ocorrem as manifestaçóes da glossolalia podem ser muito variadas, como durante o trabalho, na rua e na escola, o mais comum, no entanto, são as ocorrências durante o culto. Durante a pesquisa de campo, obtive relatos de fiéis que afirmavam conhecer outros crentes que foram batizados enquanto dormiam, ou ainda participando das campanhas de oração - que ocorrem na Igreja ou na casa de algum irmão - onde os fiéis são batiza- dos no Espírito Santo, curados de alguma enfermidade, e assim, recebem bênçãos e outros dons. Vejamos alguns depoimentos significativos a esse respeito:

\section{1) a superaçáo da dúvida e o encontro com a dádiva:}

Eu recebi o dom de línguas depois de muito buscar a presença de Deus. Eu sempre busquei e sempre orei, só que dentro de mim eu tinha uma dúvida. Só depois que eu comecei a freqüentar o monte e ler a Bíblia, os irmãos começaram a dar umas dicas de porque eu não recebia o dom. Então, eu comecei a trabalhar em cima daquilo [...] que é não duvidar. Quando eu fui batizado eu me senti como se estivesse voando, para fora desse mundo [...] senti Deus muito perto de mim e comecei a falar como se Ele estivesse muito perto. Em um culto da mocidade eu estava quase explodindo da presença de Deus e então o irmáo Antonio Carlos falou que eu estava para receber o dom; era só buscar mais um pouco e deu-me um abraço e nossa...eu comecei a falar em línguas (22 anos, metalúrgico).

2) o desejo de ser batizado, atendendo ao chamado e o recebimento do sapato de fogo:

Eu fui a um congresso (evangélico) e vi várias pessoas falando em línguas, e senti o desejo de ser batizado também. Então, por três meses orei, fazendo jejum, campanhas, ia aos montes buscar a Deus. E um irmão disse para eu ir buscando que eu ia receber. Num culto da mocidade no Jockey Clube (um bairro próximo) eu estava jejuando e disse: hoje, em nome de Jesus, Deus vai me batizar com o Espírito Santo. Cheguei lá e entrei no manto com Jesus e os irmãos disseram: Quem quer ser batizado venha à frente. Ai eu fui e o irmão me falou: Receba o sapato de fogo dos pés à cabeça, e eu comecei a falar em línguas estranhas (17 anos, serviços gerais). 
3) a necessidade de ajuda espiritual na libertaçâo dos vícios:

A minha experiência no batismo com Espírito Santo, o dom de falar em línguas foi logo quando eu me converti, eu aceitei Jesus por necessidade de ajuda. Fui à Igreja e lá me deram uma ajuda espiritual. Recordo-me que estava a seis meses na Igreja e já tinha sido liberto das bebidas mas não tinha sido liberto ainda do vício do cigarro, eu não conseguia parar de fumar. [...] Fui na campanha na segunda feira e não fumei, também na terça feira não fumei, e na quarta feira eu percebi algo diferente; estávamos em oração cantando e louvando a Deus, e de repente, senti algo diferente em minha vida. A minha vida começou a se alegrar, comecei a sentir uma quentura no meu corpo. Quando eu dei por conta estava sentado, batendo palmas e depois em pé na sala dessa irmã pulando e minha língua começou a enrolar e a sair os sons como se fossem outras línguas; e eu não conseguia entender, mas havia pessoas ali que estavam entendendo, ou seja, algumas pessoas estavam interpretando o que eu estava falando (26 anos, metalúrgico).

4) batismo em vigília depois de ser provada como a última do grupo a receber o dom:

O meu batismo foi em uma vigília. Nessa vigília foram batizados minha mãe e meu irmão, e eu disse 'eu quero ser batizada também, eles foram e eu náo?'. Passaram se os dias e no ultimo dia da vigília o inimigo falava assim para mim 'você não vai ser batizada não'. A oração já tinha terminado, demos as mãos para irmos embora e um irmão falou para orarmos mais uma vez, e ele me colocou no meio daquele círculo, e fui batizada com o Espírito Santo, mas eu só fazia barulho, sentia o poder, mas só fazia barulho. Eu tenho dom de variedade de línguas. Quando eu fui batizada eu só fazia barulho, eu pensava assim 'eu não posso só ficar fazendo barulho, tenho que falar a língua mesmo’. Em uma vigília uma irmã colocou a mão sobre mim e eu comecei a orar o começo da língua estranha (22 anos, confeiteira).

As imagens apresentadas nos relatos que versam sobre a iniciação ao dom entre os fiéis pesquisados são extremamente importantes na compreensão do imaginário pentecostal. $\mathrm{O}$ entrar no manto com Jesus, ou entrar no mistério são categorias de interpretação que sugerem uma adesão espiritual ao Pentecostalismo e, para nós, também a uma hermenêutica, a hermenêutica do imaginário. No conjunto de símbolos e arquétipos que dá sentido ao estado anterior à conversão, ocorre o predomínio das imagens tenebrosas do tempo. A abertura para o fenômeno da morte simbólica (com o seu consecutivo renascimento) denuncia a efemeridade do homem e da mulher, e, portanto, alude à condição humana. Algo semelhante acontece no processo iniciático da benzedeira, para quem as doenças, a audição de vozes, as provaçóes, as revelaçóes são evidências do que mais tarde será interpretado como uma eleição (Oliveira, 1985a, p. 34; Oliveira, 1992, p. 87-91).

Para Mircea Eliade, existem, pelo menos, dois lugares míticos, o cosmo e o caos (Eliade, 1996), que se apresentam inicialmente ao crente pentecostal como sendo maniqueístas: $\mathrm{O}$ Cosmo Pentecostal e o Mundo Profano. O mundo é o não-Cosmo, lugar do caos, do informe, é a habitação dos demônios. No primeiro, reina o Cristo, e, no segundo, o diabo e seus demônios. $\mathrm{O}$ estado anterior à conversão - os sofrimentos - é identificado como sendo do domínio do diabo. O domínio do diabo nasce com o pecado de Adão. Os diversos dissabores da vida são interpretados por imagens que compóem as estruturas esquizomorfas ${ }^{4}$ do imaginário (Durand,

4. Gilbert Durand caracteriza as estruturas esquizomorfas do imaginário como uma organização do aparelho simbólico regida pela disjunção e pela antítese (Durand, 1997a). 
1997a, p. 179-180). Nesse momento, há sempre um inimigo a ser combatido, e deve ser eliminado, quando a alteridade é suprimida. Para a cultura pentecostal, no interior desse mundo dividido em dois (o cosmo e o caos) as faces do tempo e da morte apresentam-se também sob a forma da serpente, do fervilhar, do caos, do Armagedon e do Juízo Final, quando os nãocrentes ajustarão as contas com a divindade. $\mathrm{O}$ mal ou o inimigo também aparece sob a forma de um grande lobo ou sapo, ou algo híbrido como a aparência de um ser humano com os dedos de um sapo, segundo o relato de alguns fiéis por mim entrevistados. O simbolismo teriomórfico - imagens que tomam as formas de animais - revela uma angústia que é mobilizada na mudança, na conversão e na metamorfose, e a crença em entidades maléficas dessa natureza pressupôe uma "valorização negativa do simbolismo animal" (Durand, 1997a, p. 83).

$\mathrm{Na}$ cultura pentecostal, a tribulaçáo e as obras da carne, analogicamente, também são categorias internas de interpretaçáo que marcam esse primeiro momento da iniciação entre os crentes pentecostais pesquisados. Ninguém nasce atribulado, a tribulação é um estado da alma em que a pessoa se encontra desorientada, nervosa, impaciente, sem fé. Tanto o crente como qualquer outra pessoa pode estar atribulada, a diferença é que um crente não pode ser possesso por um demônio, já o incrédulo pode. Mas essa distinção também não é tão precisa, pois, existem fiéis que afirmam que o cristão pode ser possesso caso abandone a Deus e a Igreja. Aqueles que são fiéis também podem ser influenciados pelo diabo, estão sob os efeitos da tribulação, estão sendo oprimidos, mas não são possessos. Conheci fiéis que diziam ter o dom de visão, e que, às vezes, caminhando nas ruas viam vultos acompanhando certas pessoas, ou então, viam uma infinidade de seres espirituais híbridos - macacos com rosto humano e olhos vermelhos, lobos enormes que ficavam do lado de fora da Igreja aguardando seus hospedeiros, os atribulados.

O simbolismo animal pode ter um sentido que nos ajuda compreender o processo iniciático. Segundo Chevalier e Gheerbrant, essas imagens podem assumir as formas de um psicopompo, que é um guia, um condutor, um espírito que orienta o iniciado (Chevalier; Gheerbrant, 2005, p. 557). Gilbert Durand, quando analisa os símbolos animais como Cérbero (o cão que guarda os portais do Hades), Fenrir e Managamr (os lobos que, respectivamente, devorarão o Sol e a Lua no fim dos tempos, na mitologia nórdica), afirma sobre a imagem do lobo:

Há [...] uma convergência muito nítida entre a mordedura dos canídeos e o temor do tempo destruidor. Cronos aparece com a face de Anúbis, do monstro que devora o tempo humano ou que ataca mesmo os astros mensuradores do tempo (Durand, 1997a, p. 86-87).

Uma outra categoria de interpretação, a carne ou estar na carne não se refere apenas aos pecados cometidos por meio do corpo, como as relaçóes sexuais consideradas ilícitas pelo grupo - adultério, fornicação, relações prénupciais, masturbação - mais ainda, a gula e o uso de drogas, álcool e cigarro. Estar na carne alude ainda a mentiras, a falsas promessas, a interpretações falazes da Escritura. Envolve um gradiente mais amplo de relaçóes e situações, como por exemplo, quando alguém profetiza ou entrega uma mensagem e o que foi dito não se cumpre, costuma-se dizer que tal pessoa falou de sua própria carne e náo do Espírito Santo. Houve o caso de um rapaz que falava em línguas o tempo todo, na Igreja, andando pelas ruas, no trabalho. Os outros fiéis diziam a ele para vigiar, isto é, ficar atento com as coisas sagradas, não expô-las ao léu, irresponsavelmente, pois, muitas pessoas que não conhecem a 
glossolalia podiam pensar que ele fosse louco. Algumas pessoas da Igreja disseram-me que tal moço falava por meio da carne, ou seja, o dom dele não provinha de Deus. Quando o corpo é distinto da alma ou do espírito, para os fiéis, potencialmente eles estáo vivendo no pecado, no mal, na morte, na carne.

A mudança de destino dessas forças de Cronos começa a aparecer com as imagens da luz, os símbolos ascensionais. Aqui, "representar um perigo é dominá-lo [...] a imaginação atrai o tempo ao terreno onde poderá vencê-lo com facilidade" (Durand, 1997a, p. 123). Transeo é esse ir além, é um atravessar, é o princípio de conversão. A próxima etapa desse processo iniciático é o princípio de integração desses opostos, mal e bem, vida e morte, luz e trevas por meio do renascimento simbólico.

\section{Translatio: o nascido duas vezes}

Vivenciar certas provaçóes constitui uma das formas de acesso ao novo nascimento, que é, no meu entender, uma mudança de ênfase da visão psicanalítica - com sua teoria repressiva e pulsional da imagem, condicionadora do processo civilizacional e cultural - para a idéia de sacrifício, que opera a função transcendente, que é a resolução dos contrários, a eufemização responsável pela formação desse símbolo. Doenças, estar desempregado, trabalhar em condiçôes precárias, difícil casamento ou relação conjugal, entre outras coisas são considerados obstáculo a serem transpostos pelo crente. As provas e lutas pelas quais eles passam é uma forma de Deus moldá-los e purificá-los pela água e pelo fogo, análoga ao oleiro que molda o barro segundo a sua vontade, assim Deus trabalha o interior do crente, o que se revela nas representaçôes que eles fazem de si próprios.

$\mathrm{Na}$ tradição judaico-cristâ, a água simboliza a origem da criação, na figura do Espírito
Santo, que no princípio, pairava sobre a face das águas. A alma, segundo uma metáfora bíblica, é comparada a uma terra seca que aguarda o renascimento por meio das águas provenientes $\mathrm{da}$ divindade, "a água se torna o símbolo da vida espiritual e do Espírito, oferecidos por Deus e muitas vezes recusados pelos homens" (Chevalier; Gheerbrant, 2005, p. 17 grifos do autor). O fogo associa-se à água por evidenciar uma purificação, uma transmutação da alma na metáfora da morte-renascimento. O fogo na Bíblia possui um significado específico segundo Gilbert Durand: "na Bíblia o fogo é ligado à palavra de Deus e à palavra do profeta cujos lábios são 'purificados' com uma brasa” (Durand, 1997a, p. 176). Não é sem propósito que os fiéis denominam a glossolalia como as linguas de fogo. Isso se deve ao caráter purificador e transformador que o dom vem explicitar. No Pentecostalismo, as águas batismais e o fogo do Espírito Santo são compreendidos pelos fiéis como um momento de renascimento para uma nova vida. Nos relatos colhidos em campo pude observar que a imagem da metamorfose é uma constante neste momento do processo iniciático pentecostal:

\section{1) maior temor a Deus, maior segurança:}

Depois que Deus me batizou eu sinto mais temor no meu coração. Aí então parei de fazer coisas erradas. Parei de mentir porque o pai da mentira é o diabo. Parei de ficar xingado os outros, e parei de brigar por qualquer coisa. Quando eu não era batizado eu andava de cabeça baixa. Quando Deus me batizou passei a andar de cabeça erguida. E começou a transformação do senhor Jesus Cristo na minha vida (17 anos, serviços gerais).

\section{2) mais comedimento:}

Eu era uma pessoa que não tinha trava na língua, falava muito palavrão. Eu notei que quando eu 
recebi esse batismo eu consegui mudar (26 anos, metalúrgico).

\section{3) aquisição do dom, cura, pregaçáo e reve- laçáo:}

mudou muita coisa [...] depois que eu comecei a falar em línguas, hoje eu dei uma fracassada, mas antes...quando eu falei em línguas logo depois Deus me deu o dom de cura, o dom de pregar, o dom de revelação. É como um casamento, é uma alegria imensa (50 anos, pedreiro).

Talvez, nesse momento do processo de aquisição do dom, o aprendizado das técnicas de êxtase seja a etapa mais importante para o próprio fiel. Quando indagados sobre a possibilidade de alguém ensinar outras pessoas a falarem em línguas, os fiéis afirmaram que isso é inviável e quem exerce tais práticas está na carne, não é guiado pelo Espírito Santo. No entanto, existem alguns exercícios praticados pelos pentecostais que também são comuns a outras tradições religiosas. Entre eles a contínua repetição da palavra glória ou aleluia produz alteraçôes significativas no corpo do fiel: a respiração fica mais intensa e, conforme muda o ritmo da oração, acontecem os gritos e o choro compulsivo.

Marcel Mauss aponta a dança e a música contínua como uma das muitas formas de se alcançar outros estados de consciência pelos mágicos australianos (Mauss, 2003, p. 86). Na Renovação Carismática Católica pede-se que o não-glossólalo repita as palavras Jesus e $A b b a$ (Degrandis, 2000, p. 25), como também o Terço Bizantino, que é uma outra corrente católi$\mathrm{ca}$, orienta a que os fiéis repitam as jaculatórias: "Jesus me ajude, Jesus me cure, obrigado Jesus" (Souza, 2005, p. 40); Moshe Idel, pesquisador da mística judaica apresenta algumas técnicas para a produção de transes cabalistas, como a repetição das letras do alfabeto hebraico e dos nomes divinos, a fixação do olhar em um ponto específico (Idel, 2000, p. 142-143). Para este autor, o choro e as técnicas ascéticas combinadas - jejum, oraçóes prolongadas, luto, sofrimento auto-induzido - culminam na contemplação da Glória de Deus, a Schekhiná (Idel, 2000, p. 124). Se o estímulo de um dos sentidos tende a suprimir os demais (Idel, 2000, p. 129), por outro lado, parece existir meios de focalizar energia psíquica para alcançar os desdobramentos necessários. No Pentecostalismo, a repetição de palavras ou frases curtas tende a desdobrar-se nas vocalizaçôes glossolálicas.

O êxtase passa a ser uma forma de iniciação e a manifestação de um dom, dom de comunicar-se com o sagrado, incompreensível ao diabo, que, a todo custo, quer destruir e frustrar planos, conforme explicam os pentecostais. A nova personalidade emergente, por meio do duas vezes nascido, possui uma nova linguagem que é inteligível a Deus e também a aquele que possui outro dom, a interpretação das línguas. A glossolalia é, então, portadora dos propósitos que fundem o homem ao cosmo, e cria categorias distintas de produção do dom no interior desses iguais glossolálicos, também observado entre benzedeiras na produção do dom de benzer (Oliveira, 1992).

Assim, os simbolos ascensionais (a escada de Jacó, a pomba, o batismo), os símbolos espetaculares (a luz, a elevação, a palavra) e os simbolos diairéticos (o herói, a couraça, o fogo) invertem o simbolismo do tempo e da morte, aludidos no transeo. No debate sobre morte-renascimento, o simbolismo da escada significa a passagem de um modo de ser a outro completamente distinto, e a montanha é um símbolo isomorfo da escada (Durand, 1997a, p.128). A ida do crente pentecostal aos montes evidencia, nessa analogia, o desejo de transcendência. A pomba revela, alegoricamente, o mesmo desejo de ultrapassar a profana condição humana (Durand, 1997a, p. 133); o batismo, por sua vez, 
transforma simbolicamente o caos, o mundo perturbado pela queda, em cosmo (Durand, 1997a, p. 145). Para Chevalier e Gheerbrant o batismo é um rito que co-implica na purificação e renovação, cuja "liturgia simboliza e realiza, na alma do batizado, o nascimento da graça, principio interior de aperfeiçoamento espiritual" (Chevalier; Gheerbrant, 2005, p. 126-127). No Pentecostalismo as metáforas mais correntes são a do fogo e a da palavra.

$\mathrm{Na}$ tradição bíblica é pela palavra, o Verbo Criador, que todas as coisas vêm a existir ${ }^{5}$, já que a palavra cria e ordena o mundo (Eliade, 2002, p. 333). A recitação de fórmulas mágicas, as preces, as jaculatórias e os mantras têm a propriedade de orientar a ação da divindade, como também domam todo o Universo (Durand,

5. Uma infinidade de teogonias e cosmogonias aludem à obra da Criaçáo por meio do pensamento e/ou da palavra conforme podemos ver com Mircea Eliade: 1) relato de um índio winnebago, "O Criador da Terra pôs-se a cogitar novamente. Pensou: ' assim é, qualquer coisa que eu deseje torna-se realidade. [...] então desejou a luz e a luz se fez" (Eliade, 2004, p. 67-68); 2) cosmogonia e teogonia egípcias, "O Senhor de Todos diz: quando eu passei a existir, os seres passaram a existir, todos os seres passaram a existir depois que eu vim a ser. Muitos são aqueles que vieram a ser, que saíram da minha boca [...] de minha boca os fiz sair" (Eliade, 2004, p. 73); 3) gênese Zuni, "no princípio da nova criaçáo, Awonawilona concebeu dentro de si mesmo e projetou para fora de si, no espaço, o pensamento, que originou e sublimou brumas de expansão, vapores com poderes de crescimento" (Eliade, 2004, p. 90). A literatura fantástica também oferece exemplos da criação por meio do pensamento e da palavra, como em $O$ Silmarilion de J.R.R. Tolkien: "Havia Eru, o Único, que em Arda é chamado de Ilúvatar. Ele criou primeiro os Ainur, os Sagrados, gerados por seu pensamento" (Tolkien, 2002, p. 03); como também nas Crônicas de Nárnia de C. S. Lewis: "o Leão [Aslam, o criador] andava de um lado para o outro na terra nua, cantando a nova canção. [...] à medida que caminhava e cantava, o vale ia ficando verde de capim” (Lewis, 2005, p. 59). 1997a, p. 155). A potência da palavra traduz-se tanto pela escritura como pelo fonatismo (Durand, 1997a, p. 157). O fogo é purificador, é isomorfo do pássaro e da asa enquanto símbolos ascensionais e, neste sentido, também suscita uma transcendência (Durand, 1997a, p. 173175). Translatio é essa vivência metafórica do sagrado, da morte e renascimento simbólicos.

\section{Transitio: completando a revelação do mistério, a legitimaçáo}

Por ser um dom institucional e passível do controle da Igreja, mas com um conteúdo mágico, a glossolalia ora aproxima-se ora afasta-se de uma outra forma de se conceber os dons, em especial o de benzer. As benzedeiras, apesar de professarem uma crença - católica, kardecista, crente, esotérica, umbandista - têm uma relativa autonomia na condução de seu ofício. Elas podem selecionar seus clientes e estipular várias formas de pagamento pelos seus serviços (Oliveira, 1992, p. 42, 55). Muitas vezes a instituiçâao concorre com as benzedeiras, mas, talvez, o que melhor caracterize as benzedeiras seja a sua autonomia profissional (Oliveira, 1985a, p. 38). Interessante notar que apesar da ênfase atribuída à experiência de salvação, pertencente ao domínio da singularidade de cada um, os pentecostais constroem uma série de artifícios de controle sobre a glossolalia. A instituição estimula a busca desses estados de consciência porque vê neles a possibilidade de diálogo com o sobrenatural, mas, concomitantemente os regula, orientando a açáo dos mesmos e seus limites (Hervieu-Léger, 1997, p. 36), daí que a autonomia entre os glossólalos seja restrita. Essa dimensão do controle das instituiçôes religiosas sobre os fiéis também ocorre nos candomblés, como relata Monique Augras:

Além da aprendizagem dos gestos estipulados, nos quais se incluem os movimentos da dança, a 
construção ritual do corpo e do espaço passa indubitavelmente pela descoberta das proibiçôes. [...] alimentação, banhos, regulamentação da atividade sexual, roupas, condiçóes de ingresso nos diversos locais sagrados, dança, ordem de procedência e profilaxias várias, organizam-se em modos de construção do corpo e do espaço (Augras, 1986, p. 197).

Quando questionados como se dá a legitimação do dom pela Igreja, ou seja, como sabemos que uma pessoa recebeu o Espírito Santo, as respostas não são uniformes. Talvez estejamos diante da evidência de um tipo de controle muito peculiar, que não obedece a regras fixas, nessa instituição, que como outras vive uma pluralidade simbólica, característica de vários ramos do Protestantismo, e de forma especial do Pentecostalismo, onde a liberdade do fiel para reconstruir o corpo doutrinário, o que pode explicar as inúmeras divisóes ocorridas no interior do Protestantismo. De forma distinta, mas até certo ponto parecida, as benzedeiras produzem as suas benzeções num crescendum, dos familiares aos de fora (Oliveira, 1985a, p. 40). Vejamos como os próprios glossólalos reconhecem quem possui o dom de línguas:

\section{1) o reconhecimento por meio de sinais per- cebidos por outros:}

Sei que uma pessoa recebeu o dom, pois, quando você está falando em línguas a pessoa que está perto, do seu lado, ela sente [...] porque o corpo da pessoa começa a arrepiar e começa a sentir uma coisa diferente e sente vontade de chorar. Ela começa a sentir a presença de Deus só de estar do lado daquela pessoa, eu posso falar em línguas, mas a graça do Espírito Santo a pessoa sente. Você sente o transbordar. Uma vez eu estava em Ribeirão Preto e uma mulher começou a falar em línguas, e eu senti a igreja de Ribeirão Preto tremer (29 anos, vendedor).
2) a autoridade e a conviç̧áo naquilo que se faz:

As pessoas sentem que uma outra pessoa tem o dom de línguas quando existe um transbordar de poder, você vê que a pessoa está com autoridade, convicção daquilo que está fazendo. A pessoa começa a mudar o jeito dela de proceder, ela fica mais agradável, você gosta de ficar mais tempo do lado dela (22 anos, metalúrgico).

3) o reconhecimento por meio do dom de interpretação das línguas e discernimento dos espíritos:

Para saber que uma pessoa tem o dom é preciso ter um outro dom, o dom de interpretação ou o dom de discernimento dos espíritos. Nós que somos pastores da igreja procuramos receber esses dons para melhor administrá-la (26 anos, metalúrgico).

4) a capacidade de comunicaçáo entre aqueles que possuem o dom:

Você sente que outras pessoas têm o dom de línguas, você até consegue se comunicar com ela se ela tem o dom de línguas (22 anos, confeiteira).

\section{5) o dom sempre expressa o poder de ser re-} conhecido:

Eu sei que uma pessoa tem o dom se ela manifestar as línguas. Se ela for orar, manifestar. Não tem como eu saber se a pessoa não manifestar (50 anos, pedreiro).

Apesar dessa dimensão da legitimação do processo de iniciação do dom de línguas, em que cada fiel pode sentir que essa ou aquela pessoa possui a glossolalia, os mecanismos institucionais se reproduzem criando normas 
para a manifestação e o controle desses dons espirituais. Algo semelhante também ocorre na Renovação Carismática Católica, para quem os procedimentos mágicos na liturgia são vistos como uma forma de se reavivar a igreja e, concomitantemente, os chamados excessos sáo proibidos, como o repouso no Espírito (Souza, 2005, p. 22, 29). Vários fiéis da Assembléia de Deus confidenciaram-me que tinham uma predileção pelas vigílias feitas nas matas e nos montes. Apesar de estarem ali reunidos como Igreja, e participando desses encontros aqueles irmáos que tinham maior afinidade entre $s i$, às vezes, somente um grupo de rapazes, eles alegam preferir esses encontros por sentiremse mais à vontade para fazerem suas oraçóes, $\mathrm{e}$ também porque nesses encontros o poder de Deus é maior.

Mesmo no interior da instituição, o corpo do glossólalo tem expressão, não é inerte. O uso sagrado do corpo é evidente nas representações pentecostais. A percepção do corpo é mais clara neste momento quando se fala em línguas; sente-se o corpo esquentar ou ficar mais leve, também são comuns arrepios, aceleram-se os batimentos cardíacos e a respiração. Parece que existe um maior controle sobre os usos do corpo, nesse contexto repressivo - onde a dança em festas e bailes é proibida, os homens não podem usar bermudas e nem andar sem camisa ou camiseta, as mulheres só usam saias e relações sexuais são proibidas antes do casamento - há inevitáveis desdobramentos em outras direções, a espiritual, por exemplo. Vejamos como o glossólalo representa seu corpo, sua corporeidade, e como nele sente o poder e o compreende como cogito corporal:

\section{1) o corpo é o templo do Espírito Santo:}

O Espírito Santo faz morada em nosso corpo. Você aceita Jesus Cristo como seu salvador, ele anda do seu lado. Ele se apossa de você e você sente seu corpo leve. Quando você vai fazer as coisas que fazia antes, por exemplo, eu fumava e se vou fumar hoje ele (o Espírito Santo) diz não, isso é errado. Drogas eu não uso mais, pois o Espírito Santo me limpou. Por isso você tem que buscar, porque ele não vai se apossar sem pedir licença como está escrito eis que estou a porta e bato (29 anos, metalúrgico).

\section{2) o corpo é um templo limpo e já habitado:}

Deus pegou a casa suja, limpou e fez um templo onde ele habita vinte e quatro horas por dia, por isso tenho que ter reverência com meu corpo. Eu não posso usar certos tipos de narcóticos, químicas, não posso expor meu corpo publicamente, tenho que me reservar (22 anos, metalúrgico).

\section{3) o corpo como morada do Espírito Santo:}

Quer dizer que o Espírito Santo habita em nós. E ele habitando dentro de nós, isso quer dizer que nós devemos cuidar desse templo (26 anos, metalúrgico).

\section{4) o coração como metáfora da Igreja:}

É como se eu fosse uma Igreja ele habita em nosso coração (23 anos, técnico de som).

\section{5) o corpo purificado como espaço sagrado:}

É um lugar onde Deus habita. Deus é puro, e não habita em lugar sujo, então temos que purificar o corpo (50 anos, pedreiro).

\section{6) corpo como casa de Deus:}

É a morada de Deus, é como se fosse a casa de Deus (48 anos, dona de casa). 
Para Merleau Ponty, o corpo é uma mediação simbólica, por isso, segundo ele, temos consciência do mundo por meio do corpo, e justamente esse corpo, é que garante a "metamorfose das idéias em coisas" (Merleau Ponty, 1994, p. 122, 227). Esse é o cogito corporal. Todo corpo, segundo a Antropologia do Imaginário, contribui na formação dos símbolos (Durand, 1997a, p. 50). Nessa construçáo da corporeidade, os schèmes (esquemas) são a base bio-fisiológica das imagens e os arquétipos constituem as substantificaçóes dos esquemas (Durand, 1997a, p. 60). Isso me possibilita pensar, confluindo com Hervieu-Léger e Oliveira Júnior, a glossolalia como o "engajamento do corpo na oraçáo" (Hervieu-Léger, 1997, p. 33), como também o dom de línguas mobilizando todo o corpo do fiel (Oliveira Júnior, 2004, p. 164). Desse corpo individual, do conjunto dos corpos operando por ressonância imaginal, posso compreender o dom de línguas como uma "epifanização do corpo comunitário" (Maffesoli, 2004, p. 155156). Nesse olhar que compreende a corporeidade e a gestualidade - que dão uma dimensão material a este estudo - construo uma significação muito específica das relaçôes sociais. Temos aqui uma mediaçáo de sensibilidades, ao contrário do contrato social ou do racionalismo. À busca de sentido nos símbolos da cultura pentecostal explicita os vínculos que transcendem o espaço da Igreja, e organiza simbolicamente a cultura pentecostal no interior da instituição, externamente alarga a experiência de transitividade entre os salvos e não-salvos. Nessa espécie de continuum, o produzido é ao mesmo tempo produtor de uma metamorfose no neófito. A glossolalia como símbolo faz a mediação entres os mundos sensível e inteligível e, por isso, não se constitui, na minha interpretação um signo, essa redução biográfica que possibilitaria pensála como uma psicopatologia.

É essa sensação de ser participante, por meio do corpo, das coisas sagradas que o crente luta para não perder. A glossolalia exige manutenção, procura-se participar regularmente das reuniôes da Igreja, caso contrário, correse o risco de esfriar na fé (outra categoria de interpretaçáo dos pentecostais), de perder o dom; as oraçóes também são uma das formas de santificar-se, assim como o jejum, a participação da ceia e a leitura da Bíblia. Caso esses ritos não sejam observados corre-se o risco de um retorno ao estado anterior à conversão e a uma provável perda do dom de línguas. Quem participa das coisas sagradas pertence a um sistema ontológico diferenciado e a ruptura desses laços vitais pode significar a dilaceração da identidade mítica em formação (Eliade, 2002, p. 23).

Transitio articula a construçáo do corpo, enquanto habitação divina, encarnando na pessoa, e por meio de mediaçóes simbólicas, regula a construção da identidade e da alteridade, como também as interdições institucionais sobre o dom. Assim, a glossolalia parece situarse no cerne de duas forças: de um lado, o sagrado instituinte, que pulsa no interior do fiel e, de outro, a religião instituída, com suas regras, normas e tabus, os mecanismos de regulaçáo do dom. A tomada de consciência do corpo é uma forte evidência da mudança de regime do imaginário, neste caso o trânsito do regime diurno para o regime noturno do imaginário (Durand, 1997a, p. 202). Não há mais cisôes, o profano está no sagrado, o sagrado está no profano, caem as fronteiras, o dentro e o fora começam a se dissipar, corpo e alma se integram e a divindade se revela em nosso interior.

\section{Transcendo: discernindo os espíritos}

Momento culminante do processo de aquisição do dom de línguas e de sua eficácia simbólica e imaginal. Transcendo é um ir além, é 
uma escalada em busca da compreensão da condição humana. Neste momento da pesquisa sobre o fenômeno da glossolalia é interessante observar que não é mais necessário um inimigo a ser destruído, como quando na mobilização do mito do herói, mas sim um elemento a ser agregado, integrado subjetivamente. Novamente aqui encontro apoio no estudo de Oliveira, para quem o modelo etiológico da biomedicina produzindo cisōes (corpo/alma/ relaçôes sociais) não leva em conta a cultura do doente, além de não discutir as especificidades histórico-sociais do adoecer humano (Oliveira, 1998, p. 56, 69). Por outro lado, as cisóes produzidas pelo modelo biomédico não existem nas representaçóes do pensamento popular (Oliveira, 1998, p. 47).

Os exorcismos e as manifestações de êxtase coletivo, no Pentecostalismo, sáo meios de diagnóstico, como também, proporcionam uma dimensão terapêutica nos cultos. O imaginário brasileiro é povoado por uma infinidade de seres espirituais e entidades, que ganham vida no interior da Umbanda, do Candomblé e do Pentecostalismo. E todos nós estamos sujeitos ao mau olhado, as pragas, as maldiçôes e as mandingas lançadas pelas pessoas com as quais nos relacionamos cotidianamente. Tudo isso concorre para os pentecostais vincularem a possessão demoníaca a outras práticas populares, isto é, para o crente tanto quem (re)produz o feitiço, como aquele que o suscita, e também, quem o recebe (vítima) tendem a ser possessos, configurando o exorcismo como uma prática terapêutica eficaz, nos os moldes pentecostais, para vários males da alma.

A outra dimensão dessa terapêutica são as manifestaçóes da glossolalia. Não somente para o glossólalo, mas também para toda a comunidade de crentes, quando os recados e as profecias em línguas estranhas são proferidos e interpretados, levando conforto aos que passam por lutas e tribulaçôes, desemprego, doença ${ }^{6}$. São comuns os depoimentos afirmando a eficácia de um culto quente, onde ocorreram várias manifestaçôes extáticas. Os fiéis dizem sair da igreja com a cabę̧a mais leve, prontos para um novo dia, ou então, em um culto dominical afirmam recarregar a bateria para a semana. Somente o fato de entrar em uma Igreja, segundo Cecília Mariz, pode possibilitar o "sentir algo diferente" (Mariz, 1996, p. 213). Assim, a glossolalia e exorcismo fundam o Pentecostalismo como uma religiâo de cura (Pierucci; Prandi, 1996, p. 32).

Os fenômenos de exorcismo e de glossolalia, como também os êxtases no Candomblé, quando compreendidos como a dissolução do eu, sem, contudo, que sejam analisados os efeitos terapêuticos ou a metamorfose relatados pelos fiéis, segundo Monique Augras, operam uma redução do símbolo ao signo. Essa redução epistemológica obscurece o conhecimento a respeito do sagrado (Augras, 1983, p.19). Assim, é necessário a elaboração dessas forças que estão na base da condiçáo humana. $\mathrm{O}$ eu e o outro, a superaçáo dessa e de outras duplicidades

não pode ser alcançada em moldes meramente humanos [...] a conjunção dos contrários só pode ser formulada mediante o recurso à transcendência, ou seja, a vivência da alteridade é particularmente patente na experiência mística (Augras, 1978, p.57).

O Pentecostalismo muitas vezes concebe a cura "por meio da purificação dos pecados e pela conversão" (Oliveira, 1985b, p. 30). Outras

6. Durante o culto, o crente falando em línguas, dirige-se a outro fiel e entrega um recado divino, momento que é muito aguardado pelos fiéis. Às vezes, alguém interpreta o que o glossólalo está dizendo durante o êxtase, e uma outra configuração dá-se durante esse êxtase glossolálico, quando o próprio falante diz, em língua vernácula, o recado de Deus. Pela quantidade e intensidade de manifestaçóes, os fiéis classificam um culto ou uma igreja como quentes ou frios (Brandão, 1986, p. 141). 
vezes, para quem não faz parte do corpo de fiéis, recomenda-se o exorcismo, a expulsão dos demônios. Aqui o mal é necessário. Nas classificações das doenças, é necessário que o mal seja compreendido como um agregado, na verdade ele nunca é totalmente expulso, pois a possibilidade de uma reinvestida é considerável. A ênfase, no Pentecostalismo, recai sobre o "adorcismo de possessão e adorcismo de viagem" (Laplantine, 2004, p. 188-190). O adorcismo de possessão refere-se às manifestaçôes diabólicas, as irrupçôes involuntárias do mal. $\mathrm{O}$ adorcismo de viagem trata dos fenômenos de inspiração divina que, como a glossolalia, são estados da alma buscados deliberadamente.

Apesar de expressar a luta titânica de Deus contra o diabo, o Pentecostalismo me permite pensar um de seus ritos de maior projeção, o exorcismo, como uma prática terapêutica que busca agregar o diabo, através da manipulação das forças do mal, como ensina Reginaldo Prandi:

As religiôes mágicas não se caracterizam por uma luta do bem contra o mal. O sacerdócio e as prescriçôes rituais têm uma finalidade utilitária de manipulação do mundo natural e não-natural, de exercício de poder sobre forças (Prandi, 1996, p. 30).

O exorcismo e a glossolalia, dois ritos extáticos, permitem que o crente pentecostal manipule tanto as forças do bem (o Espírito Santo), como também, as forças do mal (os demônios). Essa manifestação é vital para a fundação do Reino de Deus, o cosmo pentecostal. De acordo com Carl G. Jung, essa necessidade da existência do mal sugere não mais uma trindade e sim uma quaternidade composta pelo Pater, Filius, Spiritus e Diabolus ${ }^{7}$ (Jung, 1999, p. 58, 63):

7. Jung também aponta uma outra possível configuração para a quaternidade cristã na Idade Média, que ao invés do diabo, trás a imagem do numinoso feminino, Maria (Jung, 1999, p. 58-59).
O diabo é autônomo, não pode estar submetido ao poder de Deus, pois senão não teria condiçôes de ser o Adversário de Cristo: seria apenas uma máquina de Deus. À proporção que o Uno, o Indeterminado, se desdobra na dualidade, ele se transforma em determinado, isto é, neste homem que é Jesus Cristo, Filho de Deus e Logos. Este enunciado só é possível em virtude do Uno que não é Jesus, nem Filho, nem Logos. Ao ato de amor na pessoa do Filho se contrapóe a negação de Lúcifer (Jung, 1999, p. 61).

A palavra demônio tem sua origem no latim eclesiástico com daemoniu(m), que por sua vez, deriva do grego daimōn $(\delta \alpha \mathbf{I} \mu \omega \nu)$ que procede do verbo daiesthai ( $\delta \alpha i ́ \varepsilon \sigma \tau \alpha \imath)$, repartir, dividir (Brandão, 1993, p.278). Dessa forma, viver sob domínio do daimon remete estar sob a influência das cisões natureza/cultura, imanência/ transcendência, discussão que o pensamento antropológico vem aprofundando, sobretudo pela via da tradiçấo francesa contemporânea. Divisão é obscuridade, é caos; é o pecado da situação anterior ao nascer de novo e à glossolalia. O demônio também apresenta-se sob a forma de BaalZebube (בעל זבוב) o Senhor das moscas, nosso Belzebu. Também representado, segundo alguns relatos que colhi, como um homem (ou um grande macaco) todo queimado, o que na arquetipologia durandiana representa as trevas, pois, "o diabo é sempre negro ou contém algum negror" (Durand, 1997a, p. 92). Na concepção de Chevalier e Gheerbrant:

O diabo simboliza todas as forças que perturbam, inspiram cuidados, enfraquecem a consciência e fazem-na voltar-se para o indeterminado e para o ambivalente: centro de noite, por oposição a Deus, centro de luz. Um arde no mundo subterrâneo, o outro brilha no céu [...] ele (o diabo) é a síntese das forças desintegradoras da personalidade [...] enquanto divisor, desintegrador, o diabo preenche uma função que é a 
antítese exata da função do símbolo, que é de reunir, integrar (Chevalier; Gheerbrant, 2005, p. 337 grifos dos autores).

Transcendo - por suas características de conjunção dos contrários, neste caso Jesus e o diabo - conduz-nos à eficácia imaginal. Enquanto para Lévi-Strauss a estrutura integra os pares binários opostos e complementares através de um modelo formal construído pelo pesquisador, não como uma realidade empírica; e em Radcliffe-Brown a estrutura é um padrão empírico de repetição de fenômenos, Lévi-Strauss, comentando Radcliffe Brown no texto $A$ noção de estrutura em etnologia, afirma:

[...] devo sublinhar que ele [Radcliffe-Brown] tem das estruturas sociais uma concepção diferente da enunciada neste trabalho. A noção de estrutura aparece-lhe como um conceito intermediário entre os da antropologia social e da biologia (Lévi-Strauss, 1996b, p. 343-344).

Talvez, o fato de o conceito de estrutura em Radcliffe-Brown ter um ancoramento biológico levou Gilbert Durand a aproximar-se mais desse autor, quanto ao conceito de estrutura, do que Lévi-Strauss (Durand, 1997a, p. 6364). Quanto à dimensão biológica presente na Antropologia do Imaginário de Gilbert Durand, Denis Domeneghetti Badia a compreendeu com muita acuidade, contribuindo na discussão da eficácia imaginal:

Pelo que diz respeito ao arquétipo, Gilbert Durand introduz precisóes com relação a Jung. Falando num 'platonismo etológico' o autor distingue um 'duplo grau de inatismo' no arquétipo: porque há os 'arquétipos genotípicos' [...] constituindo um capital genético, e os 'arquétipos fenotípicos', envolvendo modelos de aprendizagem e de 'imprinting'. Ora, os 'arquétipos genotípicos' são precisamente os 'schèmes' de 'Les Structures Anthropologiques de l'Imaginaire', definindo a arquetipologia geral, ao passo que os 'arquétipos fenotípicos' engendraráo imagens simbólicas e as constelaçóes de imagens simbólicas que são os mitos, definindo a mitanálise (Badia, 1999, p. 6263).

A compreensão das imagens primordiais, os arquétipos, segundo Badia, deve considerar essa dimensão material (biológica), como também todo o capital cultural encontrado nos mitos. Assim, existe a possibilidade de, geneticamente herdarmos um inconsciente repleto de imagens (arquétipos genotípicos) que assumirão as mais diversas formas e significados de acordo com a cultura na qual o indivíduo está inserido (arquétipos fenotípicos). A respeito da hipótese da hereditariedade do inconsciente, Lévi-Strauss na Introdução à obra de Marcel Mauss, ao criticar o conceito de inconsciente em Carl G. Jung, afirma que:

[...] para Jung, o inconsciente não se reduz ao sistema: ele está repleto de símbolos, e mesmo de coisas simbolizadas que lhe formam uma espécie de substrato. Ou esse substrato é inato: mas, sem a hipótese teológica, é inconcebível que o conteúdo da experiência a preceda; ou ele é adquirido: ora, o problema da hereditariedade de um inconsciente adquirido não seria menos temível que o dos caracteres biológicos adquiridos (Lévi-Strauss, 2003, p. 29).

No texto $A$ eficácia simbólica, Lévi-Strauss, apresenta uma concepção de inconsciente que organiza estruturalmente todo conflito, trauma, imagens que por ele passam, ou seja, o inconsciente para esse autor se reduz ao sistema, que é formado pelo conjunto de estruturas. Assim como o estômago, segundo a metáfora feita pelo autor, é indiferente aos alimentos que por ele passam, limitando-se a digerí-los, 
o inconsciente organiza em estruturas tudo o que por ele passa, desconhecendo o conteúdo dessas imagens. A eficácia simbólica acontece quando os elementos da estrutura mental são reorganizados cognitivamente, cada elemento assumindo o seu lugar no sistema. $\mathrm{O}$ autor nos mostra uma correspondência existente entre a estrutura mental e a estrutura corporal; ambas as estruturas são homólogas quanto à forma. Um elemento que seja reorganizado na estrutura mental ou corporal modifica todo o sistema, que é um conjunto de estruturas. No circuito estrutura mental para estrutura corporal, ou vice-versa, opera a cura:

[...] a cura xamanística e a cura psicanalítica tornar-se-iam rigorosamente semelhantes; tratar-se-ia em ambos os casos de induzir uma transformação orgânica, que consistiria essencialmente numa reorganização estrutural, que conduzisse o doente a viver intensamente um mito, ora recebido, ora produzido, e cuja estrutura seria, no nível do psiquismo inconsciente, análoga àquela da qual se quereria determinar a formação no nível do corpo. A eficácia simbólica consistiria precisamente nesta "propriedade indutora" que possuiriam, umas em relaçáo às outras, estruturas formalmente homólogas, que se podem edificar, com materiais diferentes, nos níveis diferentes do vivente: processos orgânicos, psiquismo inconsciente, pensamento refletido (Lévi-Strauss, 1996a, p. 232-233 grifos meus).

No nível mais profundo do psiquismo humano, para Lévi-Strauss, encontramos as estruturas elementares do parentesco e os mecanismos culturais reguladores do incesto como algo irredutível, universal. Mas também devemos compreender que não são as estruturas antropológicas do imaginário em Gilbert Durand que se opóem ao conceito de estrutura em Lévi-Strauss, mas sim, o conceito de trajeto antropológico ${ }^{8}$, este permite acessar os esquemas organizadores do imaginário e do inconsciente coletivo:

Não é a forma que explica o fundo e a infra-estrutura, mas muito pelo contrário é o dinamismo qualitativo da estrutura que faz compreender a forma. [...] o que nos parece caracterizar uma estrutura é precisamente que ela não pode se formalizar totalmente e descolar do trajeto antropológico concreto que a fez crescer (Durand, 1997a, p. 358-359).

O conceito de trajeto antropológico implica em gênese recíproca dos fenômenos sociais, psíquicos e biológicos na constituição dos símbolos. Para o estruturalismo de Lévi-Strauss a forma precede o símbolo e, apesar de existirem as estruturas corporais, estas não garantem a confluência do biológico ao sócio-cultural uma vez que é o inconsciente individual que opera a mediação entre os diferentes niveis do vivente. Essa é a mediação que o autor denomina eficácia simbólica. $\mathrm{O}$ mito exterior (proveniente do meio cultural), por indução e dedução, tem ressonância no corpo enfermo, operacionalizando a cura. De maneira distinta para a eficácia imaginal temos a passagem do Regime Diurno para o Regime Noturno das imagens. Através de um fenômeno denominado transdução, que é a experiência simbólica vivida, o mito encarna no indivíduo, e este o reinventa dinamicamente no interior da cultura. A eficácia simbólica difere da eficácia imaginal no sentido de que aquela pressupóe a dedução e a indução como método, ou seja, o pensamento ainda está no centro do processo de cura. A eficácia imaginal, por sua vez, opera pelo método

8. Para Gilbert Durand, o trajeto antropológico é a incessante troca que existe ao nível do imaginário entre as pulsôes subjetivas e assimiladoras e as intimaçóes objetivas que emanam do meio cósmico e social (Durand, 1997a, p. 41). 
transdutivo, centrado na vivência simbólica e na participação (no sentido dado por LévyBruhl).

Assim, a noção de eficácia imaginal torna-se mais clara a partir da compreensão do conceito de Imaginário, que finalmente, podemos apresentar ao leitor, nas palavras de Paula Carvalho, que assim o define:

[...] por um lado é o capital (inconsciente) de gestos do sapiens, portanto o "pólo arquetipal" das invariâncias tendo como componentes o campo morfogenético, os arquétipos, os chreodoi, os schèmes, os gestos e os ritos, sendo a ancoragem corporal do imaginário; por outro lado, é o complexo das polissemias simbólicas como conjuntos psico-culturais, ou seja, é o repertório dos sistemas e práticas simbólicos vistos como ideário (conjunto de ideaçôes) e como imaginaria (conjunto das imagens simbólicas), o "pólo figural" das variaçôes sócio-culturais tendo como componentes os paradigmas e sistemas conceituais, as mitologias e as utopias, as axiologias e o domínio do mítico-imaginal. O "símbolo" realiza a sutura entre o pólo arquetipal ou das invariâncias, como build, forma que é e, como sinn, sentido que é, refere-se ao pólo ideográfico-figural, sendo portanto uma uniấo de opostos e uma máquina de transformaçâo de energia: tem uma estrutura vincular e re-ligiosa, de unificar polaridades (Paula Carvalho, 1999, p. 239).

A eficácia imaginal não se reduz à forma, mas, a esta oferece um sentido desdobrado no vínculo, na conjunção dos opostos e na re-ligaçáo dos diversos niveis do vivente. No Pentecostalismo, a passagem do Regime Diurno da imagem para o Regime Noturno, no interior das estruturas sintéticas - que são estruturas que integram e harmonizam os contrários conforme Durand - implica a tomada de consciência e de integração da sombra e do mal em si mesmo. Nesse momento, no transcendo, o fiel elabora a alteridade na relação com o grupo e consigo mesmo (alteridade interior), a dicotomia interior/exterior se dissipa. O diabo, anteriormente tido como inimigo a ser combatido, é agregado na compreensão de que o mal pode surgir das profundezas do mesmo, e não somente do outro. Contudo, poucos são os fiéis que alcançam essa condição.

Apesar de a glossolalia ser o eixo teológico do movimento pentecostal, e a ênfase no discurso dos fiéis - enquanto produtores e também consumidores dos bens de salvaçáo - ser voltada à aquisição desse dom espiritual, a Igreja cria mecanismos de regulaçáo das manifestações religiosas que impedem outros possíveis desdobramentos. O vínculo institucional é muito forte entre os fiéis. Durante o trabalho de campo não conheci crentes que conseguissem relativizar sua fé. Toda a dúvida ou possíveis críticas sobre pontos doutrinários obscuros e posiçōes teológicas extremamente dogmáticas sáo consideradas como coisas do diabo. Suprimir o outro, a alteridade, é uma das muitas formas de se reforçar o mesmo. O problema consiste no fato de que ignorar a alteridade é desconhecer a si mesmo, uma vez que o dentro e o fora são construçóes da cognição. $\mathrm{O}$ diabo e as trevas exteriores podem ser os nossos demônios íntimos.

Em minha interpretação, o Pentecostalismo consiste em um movimento de ressurgência do símbolo, entre eles o dom de línguas. No meio pentecostal, o racionalismo característico do protestantismo histórico é suplantado por uma infinidade de forças arquetipais que atuam no cotidiano, ora possuindo, ora inspirando os fiéis. No entanto, isso não significa que o grupo não seja unilateral. A unilateralidade pentecostal explica o etnocentrismo dessa instituição religiosa, ou melhor, o etnocentrismo é um desdobramento dessa unilateralidade. 
Glossolalia, iniciação e alteridade no Pentecostalismo $\mid 73$

Glossolalia, iniciation and alterity in pentecostalism

abstract The gift of tongues - how the glossolalia is know among the pentecostals - is a kind of pray that the belivers, in ecstasy, express themselves by means of an aparent unintelligible language, followed by body expressions of the sentiments of happiness, overflow, weeping, laughing, jumps and gesticulation. This gift is very important in the Pentecostal Theology because it is considerated, by the believers, the irrefutable evidence of the Holy Spirit baptism. It's a ritualistic and institucional gift, that occurs durind the cult and develop itself in the institucion - it's a distinctive form of gifts that occurs in relatives self-suficients process, like the faith-realers and the witch-doctors. I analyse the process of aquisicion and development of glossolalia dialoging with the Anthropology of Imaginary.

keywords Glossolalia. Gift. Anthropology of Imaginary.

\section{Referências bibliográficas}

I CORÍNTIOS. In: Bíblia de Estudo Pentecostal. Tradução de João Ferreira de Almeida. Edição Revista e Corrigida. São Paulo: Casa Publicadora das Assembléias de Deus - CPAD, 1995. 2030 p.

ATOS DOS APÓSTOLOS. In: Bíblia de Estudo Pentecostal. Tradução de João Ferreira de Almeida. Edição Revista e Corrigida. São Paulo: Casa Publicadora das Assembléias de Deus - CPAD, 1995. 2030 p.

AUGRAS, M. O ser da compreensão. Rio de Janeiro: Editora Vozes, 1978. $100 \mathrm{p}$.

$O$ duplo e a metamorfose: a identidade mitica em comunidades nagô. Petrópolis: Editora Vozes, 1983. $295 \mathrm{p}$.

. Transe e construçáo de identidade no candomblé. Psicologia Teoria e Pesquisa. Brasília, v. 2, n. 3, p. 191-200, 1986.

BADIA, D.D. Imaginário e ação cultural. Londrina: Editora UEL, $1999.185 \mathrm{p}$.

BASTIDE, R. Os problemas da vida mistica. Lisboa: $\mathrm{Pu}-$ blicaçôes Europa-América, s/d. 185 p.

BAUBÉROT, J. História do protestantismo. Lisboa: Ediçôes Europa América, s/d. 129 p.
BRANDÃO, C. R. Os deuses do povo. São Paulo: Editora Brasiliense S.A, 1986. 306 p.

BRANDÃO, J. S. Dicionário mítico-etimológico da mitologia grega. Petrópolis: Editora Vozes, v. 1, 1993. 702 p.

CAMPOS JÚNIOR, L.C. Pentecostalismo: sentidos da palavra divina. São Paulo: Editora Ática, 1995. 168 p.

CHEVALIER, J.; GHEERBRANT, A. Dicionário de símbolos. 19. ed. Rio de Janeiro: Editora José Olympio, $2005.996 \mathrm{p}$.

CORTEN, A. Os pobres e o Espirito Santo: o Pentecostalismo no Brasil. Petrópolis: Editora Vozes, 1996. 288 p.

DEGRANDIS, R. $O$ dom das línguas. São Paulo: Editora Loyola, 2000. 39 p.

DURAND, G. As estruturas antropológicas do imaginário: introdução à arquetipologia geral. São Paulo: Editora Martins Fontes, 1997a. 552 p.

La noción de limite em la morfologia religiosa y em lãs teofanias de la cultura europea. In: Los dioses ocultos: Círculo de Eranos II. Colombia: Anthropos Editorial, 1997b. 222 p.

EFÉSIOS. In: Bíblia de Estudo Pentecostal. Tradução de João Ferreira de Almeida. Edição Revista e Corrigida. São Paulo: Casa Publicadora das Assembléias de Deus - CPAD, 1995. 2030 p.

ELIADE, M. O sagrado e o profano: a essência das religiōes. São Paulo: Editora Martins Fontes, 1996. 180 p. Tratado de história das religióes. São Paulo: Editora Martins Fontes, 2002. 480 p.

O conhecimento sagrado de todas as eras. São Paulo: Editora Mercúrio, 2004. 408 p.

FRESTON, P. Breve história do Pentecostalismo brasileiro. In: Nem anjos nem demônios: interpretaçôes sociológicas do Pentecostalismo. Petrópolis: Editora Vozes, 1996. $272 \mathrm{p}$.

HERVIEU-LÉGER, D. Representam os surtos emocionais contemporâneos o fim da secularização ou o fim da religiáo? Religiáo e Sociedade, Rio de Janeiro, v. 18, n. 1, p. 31-47, 1997.

IDEL, M. Cabala: novas perspectivas. São Paulo: Editora Perspectiva, 2000. 428 p.

JOEL. In: Bíblia de Estudo Pentecostal. Tradução de João Ferreira de Almeida. Edição Revista e Corrigida. São Paulo: Casa Publicadora das Assembléias de Deus CPAD, 1995. 2030 p.

JUNG, C. G. Interpretação psicológica do dogma da trindade. Petrópolis: Editora Vozes, 1999. 102 p.

LAPLANTINE, F. Antropologia da doença. São Paulo: Editora Martins Fontes, 2004. 274 p.

LÉVI-STRAUSS, C. A eficácia simbólica. Antropologia Estrutural. 5. ed. Rio de Janeiro: Tempo Brasileiro, 1996a. 456 p.

cadernos de campo, São Paulo, n. 16, p. 55-74, 2007 
A noção de estrutura em etnologia. Antropologia Estrutural. 5. ed. Rio de Janeiro: Tempo Brasileiro, 1996b. 456 p.

. Introduçăo à obra de Marcel Mauss. In: MAUSS,

M. Sociologia e Antropologia. São Paulo: Editora Cosac \& Naify, 2003. 536 p.

LEWIS, C.S. As crônicas de Nárnia. São Paulo: Companhia das Letras, 2005. 752 p.

LUCAS. In: Bíblia de Estudo Pentecostal. Tradução de João Ferreira de Almeida. Edição Revista e Corrigida. São Paulo: Casa Publicadora das Assembléias de Deus - CPAD, 1995. $2030 \mathrm{p}$.

MAFFESOLI, M. A parte do diabo. Rio de Janeiro, São Paulo: Editora Record, 2004. 191 p.

MAFRA, C. Os evangélicos. Rio de Janeiro: Jorge Zahar Editor, 2001. 88 p.

MARIANO, R. Neopentecostais: sociologia do novo pentecostalismo no Brasil. Sáo Paulo: Ediçóes Loyola, 1999. 246 p.

MARIZ, C.L. Libertação e ética. Uma análise do discurso de pentecostais que se recuperaram do alcoolismo. In: Nem anjos nem demônios: interpretaçôes sociológicas do Pentecostalismo. Petrópolis: Editora Vozes, 1996. $272 \mathrm{p}$.

MAUSS, M. Esboço de uma teoria geral da magia. Sociologia e antropologia. Sáo Paulo: Editora Cosac \& Naify, 2003. $536 \mathrm{p}$.

MERLEAU-PONTY, M. Fenomenologia da percepção. Sáo Paulo: Editora Martins Fontes, 1994. 662 p.

OLIVEIRA, E.R. O que é benzeção. 2. ed. São Paulo: Editora Brasiliense, 1985a. $108 \mathrm{p}$.

O que é medicina popular. São Paulo: Editora Brasiliense, 1985b. 92 p.

A profanação do sagrado e a sacralização do profano. São Paulo: Coleção Textos. UNESP Araraquara, 1992. $170 \mathrm{p}$.

Representaçóes de doença e estratégias de cura: os magos da ciência e os cientistas da magia. In: BO-

autor Maurício Ricci

Doutorando em Sociologia/UNESP

Recebido em 29/03/2007

Aceito para publicą̧ão em 26/07/2007
TAZZO, C.; TORRES, S. (Org.) Ciências sociais $e$ saúde bucal: questôes e perspectivas. São Paulo: Editora Unesp, 1998. 230 p.

OLIVEIRA JÚNIOR, A.W. Glossolalia: voz e poesia. São Paulo: FAPESP, Omni Editora, EDUC, 2004. 178 p. ORO, A.P. O Espirito Santo e o Pentecostalismo. Teocomunicação. Porto Alegre, v. 25, n. 107, p. 87-101, 1995.

Avanço pentecostal e reação católica. Rio de Janeiro: Editora Vozes, 1996. 129 p.

PAULA CARVALHO, J.C. Mitocritica e arte: trajetos a uma poética do imaginário. Londrina: Editora UEL, 1999. $247 \mathrm{p}$.

PIERUCCI, A. F.; PRANDI, R. A realidade social das religiōes no Brasil: religião, sociedade e política. São Paulo: Editora Hucitec, 1996. 296 p.

PRANDI, R. Herdeiras do axé. São Paulo: Editora Hucitec, $1996.200 \mathrm{p}$.

ROLIM, F.C. O Pentecostalismo no Brasil: uma interpretação sócio-religiosa. Petrópolis: Editora Vozes, 1985. $260 \mathrm{p}$.

ROMANOS. In: Bíblia de Estudo Pentecostal. Tradução de Joâo Ferreira de Almeida. Edição Revista e Corrigida. São Paulo: Casa Publicadora das Assembléias de Deus - CPAD, 1995. 2030 p.

SOUZA, A. R. Igreja in concert: padres cantores, mídia e marketing. São Paulo: Editora Annablume, 2005. 144 p.

TOLKIEN, J.R.R. O Silmarilion. São Paulo: Companhia das Letras, 2002. 470 p.

\section{Notas}

Este texto é parte de uma reflexão que fiz em minha dissertação de mestrado intitulada "Glossolalia e organização do sistema simbólico pentecostal", sob a orientação da Profa. Dra. Elda Rizzo de Oliveira. 